\title{
Developing and Managing Cross-Functional Teams:A Multi-Case Study of Brazilian Manufacturing Companies
}

\author{
Márcio Lopes Pimenta', Andrea Lago da Silva², Wendy L.Tate ${ }^{3}$
}

\begin{abstract}
The growth of industries and the strong economic base in Brazil require improvements and adaptations in business processes. Cross-functional teams (CFT) may help to companies achieve these improvements. This research looks at characterizing CFT according to application processes, structures, objectives and impacts, considering the context of demand planning and related processes. In-depth interviews with 22 managers were performed in three Brazilian manufacturing companies. A framework to characterize CFT and respective impacts is proposed, including elements such as: procedures, context and goals, power distribution, impacts on cross-functional integration, impacts on teams' performance and on organization's performance. One significant managerial finding is that effective and efficient CFTs need balanced distribution of power among members by effectively establishing and structuring the team. By doing this, managers may observe positive impacts on inter-functional integration and in firm's results. Moreover, teams should permanently perform joint planning to predict unfavorable situations, improve communication and mutual understanding.
\end{abstract}

Keywords: cross-functional teams; demand and supply; cross-functional integration; impacts of integration; brazilian firms.

\footnotetext{
'Management and Business College, Federal University of Uberlândia.Av.João Naves de Ávila, 2 I 2 I room IF2 I 0- Uberlândia - MG - BRAZIL ZIP Code: 38400-902. Phone: +55-34-99329989. E-mail: pimenta@fagen.ufu.br (Principal contact for correspondence)

${ }^{2}$ Department of Industrial Engineering, Federal University of São Carlos. Rod. Washington Luís - Km 235- São Carlos - SP - BRAZIL

${ }^{3}$ Department of Marketing and Supply Chain Management, University of Tennessee. 3 I 5 Stokely Management Center - Knoxville,TN - USA
}

ISSN: 07 I8-2724. (http://www.jotmi.org)

Journal of Technology Management \& Innovation (c) Universidad Alberto Hurtado, Facultad de Economía y Negocios. 


\section{Introduction}

In spite of its current historical economic development phase, Brazil presents a number of problems such as a low GDP rate, lack of an efficient transportation infrastructure, and recent uncertainty from international investors due to the government difficulty to control inflation. Many of these economic problems are related to the low performance of the industrial sector (Leahy, 20I4). In such a landscape, companies must innovate their products and processes in order to be effective in the global market competition. One managerial perspective that can help to develop an innovative culture, within these companies, may be the concept of cross-functional integration, widely studied in the Supply Chain Management literature (Daspit, Tillman, Boud, and Mckee, 2013; Daugherty, Chen, Mattioda, and Grawe, 2009; Kahn, 1996).

An important aspect of cross-functional integration relates to the use of integrating mechanisms in activities that require expertise from different functions (Maltz and Kohli, 2000). The level of inter-firm integration depends on the efficiency of cross-functional relations among people and crossfunctional teams (CFT) could be viewed as a mechanism to improve the efficiency of these relations (Topolšek and Čurin, 2012). According to Maltz and Kohli (2000), CFT are permanent or temporary groups aimed at reducing conflicts in goals, language and processes that require cross-functional integration. These groups facilitate the interaction of members of distinct functions while performing temporary tasks, such as the development of new products (Turkulainen and Ketokivi, 2012), or in permanent departments that aim to integrate operational processes (Pagell, 2004).

The use of CFT to collaboratively engage in business processes is increasing as companies implement changes that may demand participation of different types of members, including clients (Webber, 2002). Such characteristics of the modern organization requires an understanding of team functioning in order to accomplish tasks that demand multiple knowledge and skills (Katzenbach and Smith, 1993). However, the simple existence of a CFT is not enough to guarantee success in terms of performance. It is also necessary to obtain additional structures and support from top management (Proehl, 1997). In addition, many organizations do not use CFT efficiently because of a lack of knowledge about that tool and its respective benefits (Henke, Krachenberg, and Lyons, 1993).

In previous research, some authors simply mention CFT as one of the integration factor used for achievement of crossfunctional integration (Lambert and Cook, 1990; Flint et al., 2008). Other research provides specific analysis of CFT according to their operational characteristics and impacts in the following contexts: NPD (Henke et al., 1993; Feng et al., 2010), project teams (Pinto et al., 1993; Kotlarsky et al., 20I2) and operations (Lichtenstein, Alexander, McCarthy, and Wells, 2004). However, this previous research does not provide any explanation about team characteristics in a context of demand and supply management, considering its processes, structures, objectives and impacts on performance. Instead, these elements are limited in the literature, mostly concerned about the relationship between some CFT specific characteristics and group success.

In an emerging country, like Brazil, best practice and process improvements are necessary. With CFT there is a need to understand the application processes, structures and context of the CFT and a means to link these different elements to a wide range of performance items. The overarching purpose of this research is to answer the following question:

How can cross-functional teams be implemented in order to improve inter-functional integration between demand and supply activities in Brazilian manufacturing organizations?

In order to answer this question, using case study data of Brazilian organizations, cross-functional teams are characterized according to the application processes, structures, objectives and impacts. The next section addresses the existing literature including empirical results of papers that studied CFT in several different contexts. This is followed by the methodology, with explanations about the multi-case study performed in Brazil. The manuscript closes with an analysis of results, implications and conclusions.

\section{Literature Review}

Cross functional teams are defined as groups aimed at developing opportunities that require diverse expertise and induce/instigate people from different functions to work together, establishing and communicating the rewards for collaborative behavior (Pagell, 2004). Cross-functional teams (CFT) need both time and resource investments to generate common commitment toward the achievement of both collective and individual goals. Members of cross function teams must think and act jointly, in order to produce something beyond end products (Katzenbach and Smith, 1993; Feng et al., 2010). Cross-functional teams are considered effective because they:

- reduce hierarchical centralization, speeding-up processes and increasing market responsiveness (Henke et al., 1993);

- $\quad$ provide better quality of decisions in comparison with individual decisions (Henke et al., 1993);

- form informal networks that improve communication (Maltz and Kohli, 2000); 
- maintain focus on the organization's broad goals (Maltz and Kohli, 2000);

- $\quad$ provide increased responsiveness to the market (Rho, Hahmb, and Yu, 1994);

- $\quad$ reduce conflicts and language barriers (Griffin and Hauser, 1996).

\section{CFT's characteristics and usefulness}

There are both long-term and temporary project teams. Longer-term teams tend to have more commonalities among members which generally helps to facilitate better group performance (Katzenbach and Smith, 2003). Webber (2002) characterized CFT from three basic elements: functional diversity, time allocation, diversity and multiple reporting relationships. Findings from Webber's (2002) performance indicated that the higher the heterogeneity among the elements, the lower the level of trust among the participants in the CFT. Group leaders found that reducing diversity generally increases trust.

In the pursuit of investigating the knowledge-sharing phenomena within CFT's, Ghobadi and D'Ambra (20I2) conducted a survey with software development group leaders in Australia. These authors evidenced that different characteristics of internal competition could originate mixed impacts: competition for tangible resources positively affects cooperative communication. Alternatively, competition for intangible resources (like political interests) negatively affects both cooperative communication and task orientations.

McDonough III (2000) proposed a model to demonstrate the factors contributing to NPD cross-functional teams success. According to him, CFT performance is influenced by three types of factors:

- $\quad$ stage setters: project non conflicting goals, empowerment, human resources prepared to work in group, adequate climate;

- $\quad$ enablers: team leaders efforts for integration, top management support, champions (informal leaders);

- team behaviors: cooperation, commitment, ownership, trust.

CFT's are an important tool used to overcome inter-functional barriers, but to be effective, managers must promote mutual understanding among members (Majchrzak, More, and Faraj, 2012). Different ways of intense interaction are necessary to expand knowledge beyond functional silos, and also among different project teams. According to Ratcheva (2009), the CFT comprises the interaction through: accomplishment of the boundary spanning activities, professional commonalities and social commonalities. More recently,
Anthony et al. (2013) found that high levels of inter-functional integration in the firm contribute to reduce conflicts within NPD teams.

Teams with members located in different countries should have mechanisms to overcome the effects of the geographical and time diversities. These undesired effects can be avoided through integration mechanisms including reward systems based on team indicators, job rotation, information technology and power of the leader to support the team (Hauptman and Hirji, 1999). Pinto et al. (1993) analyzed cross-functional project teams in U.S. hospitals and identified important factors to generate cooperation and task accomplishment, such as: alignment of goals, physical proximity and formalization of team rules and procedures.

In the context of NPD, Jugend and Silva (2012) highlighted mechanisms to synchronize product and technology development processes. According to this research, the addition of practices like job rotation and inter-functional meetings in CFT may accelerate NPD processes, and help to accomplish activities according to the scheduled timeframe. In that same NPD context, Holland, Gaston and Gomes (2000) suggest three critical factors for success in CFT applied on new product development: strategic alignment between functions, organizational support for team and project needs, and a culture which prizes teamwork, i.e. team based accountability. These authors also highlight that team leaders should be able to promote teamwork, managing the boundary spanning activities and members' needs. Meanwhile, team members need to have openness to change, trust, and ability to deal with personal conflicts.

CFT members should realize that roles within CFT's can introduce differences in both status and treatment within the group. These status differences may negatively affect team functioning. Lichtenstein et al., (2004) studied this particular issue in the healthcare context, and concluded that hierarchy status differences generate consequences in attitudes and behavior of members.

The finding that higher status clinicians are more likely than individuals with lower occupational status to actively participate in team discussions suggests that relationships defined in broader social contexts affect status, roles, and functions within the medical team setting and, in turn, affect the team's interpersonal processes (Lichtenstein et al., 2004: 332).

Daspit et al. (2013) argued that the level of effectiveness of CFT can be increased as: I) their members engage in activities in which leadership is shared among members; and 2) a positive internal environment within CFT exists, because it generates cohesion among members. 
Katzenbach and Smith (1993) propose that team members must have three different types of skills in order to achieve effectiveness: technical or functional expertise, problem solving and decision making (managerial skills), and interpersonal skills. Feng et al. (2010) highlight that team members have to be selected based on their ability to generate high levels of both individual and collective performance.

It overcomes the limitations that occur in the existing methods considering either the individual performance or the collaborative performance. It also helps to reduce the uncertainty regarding the cooperation among the potential members (Feng et al., 2010:661).

\section{Summary of Existing Literature}

After an analysis of the extant literature, some thoughts may be delineated. Most of the literature brings about NPD and project teams, e.g. (Anthony et al., 20 I3; Holland et al., 2000; Jugend and Silva, 2012). Cross functional teams are presented as tools to bring people from different functions together in order to perform boundary spanning activities within organizational processes (Maltz and Kohli, 2000; Topolšek and Čurin, 2012). Moreover, the use of CFT may be a source of positive impacts, such as: improvement of results in the organization level (Henke et al., 1993; Maltz and Kohli, 2000; Rho et al., 1994) and improvement of cross-functional integration (Griffin and Hauser, 1996; Maltz and Kohli, 2000). Finally, the main characteristic of CFTs is the knowledge diver- sity among their members (Katzenbach and Smith, 2003). In spite of this, some interpersonal commonalities are required to improve communication and group vision (Majchrzak et al., 2012; Ratcheva, 2009). These impacts help to align team members toward the reaching of common goals.

Based on the review of the literature, a clear gap was discovered. There is a need to empirically operationalize and understand the workings of the CFT with the area of demand and supply management. In-depth case studies that consisted of a number of CFT were performed. The methodology below discusses the design of the research study.

\section{Methodology}

After the literature analysis, that revealed an exploratory status of the theme addressed in the research problem, indepth case studies were performed in Brazilian manufacturing companies that efficiently use cross-functional teams to manage processes related to demand and supply. Three companies from different industries were selected. Glaser and Strauss (1967) noted that the researcher, instead of seeking homogeneous cases, may seek to maximize differences in case selection. This allows for the opportunity of identifying different elements/categories and also the various semantic definitions for these categories. Besides this primary criterion, heterogeneity of constructs, the selection of cases considered other criteria contained in Table I. Table 2 summarizes the primary demographics of the study organizations and the respective CFTs.

\begin{tabular}{|c|c|}
\hline Criterion & Definition \\
\hline Medium or large companies & $\begin{array}{l}\text { The larger the organization the more complex the cross-functional actions tend to be, } \\
\text { involving a larger amount of resources spent on integration, varying degrees of decen- } \\
\text { tralization of decisions and physical dispersion of activities (Dawes and Massey, 200I; } \\
\text { Paiva, 2010). }\end{array}$ \\
\hline $\begin{array}{l}\text { Manage boundary spanning activities be- } \\
\text { tween Marketing, Logistics and Manufac- } \\
\text { turing functions, and perform initiatives } \\
\text { to integrate them through CFT }\end{array}$ & $\begin{array}{l}\text { This criterion was previously identified through exploratory interviews with people in } \\
\text { senior management or persons that could indicate potential interviewees and authorize } \\
\text { the research. }\end{array}$ \\
\hline $\begin{array}{l}\text { The organizations surveyed work with } \\
\text { critical products and processes in turbu- } \\
\text { lent environments }\end{array}$ & $\begin{array}{l}\text { Extremely competitive markets require interfaces between Logistics and Marketing for } \\
\text { competitiveness, for the storage, handling and transporting essential items are suitable } \\
\text { for adding value to the final product (Lynch and Whicker 2008; Hilletofth, Emerson, and } \\
\text { Christopher 2009). }\end{array}$ \\
\hline $\begin{array}{l}\text { Located } 500 \mathrm{~km} \text { up to a maximum of the } \\
\text { research center (São Carlos-SP) }\end{array}$ & $\begin{array}{l}\text { As a matter of time limit and budget. Therefore, it became feasible to carry out multiple } \\
\text { visits within a time period limited to them. }\end{array}$ \\
\hline
\end{tabular}

Table I. Criteria for selection of participating organizations

ISSN: 07 I8-2724. (http://www.jotmi.org)

Journal of Technology Management \& Innovation (c) Universidad Alberto Hurtado, Facultad de Economía y Negocios. 
Twenty-two in-depth interviews were conducted with CFT members and others that were related to the outcome of group decisions that were made during 20II.Table 3 details the characteristics of interviewees.

The data collection procedure followed a Grounded Theory approach which provided some guidelines for producing knowledge directly from field phenomena (Glaser and Strauss, 1967). Such an orientation was adequate to the proposed objective of this research since the research question for this paper is related to an application context poorly discussed in the existing literature.
The questions discussed during the interviews primarily focused on the team's procedures as well as its impacts on integration and company performance. First, respondents were inquired about what activities demand cross-functional integration through CFT and its respective impacts over performance. After that, they were questioned about CFT structural characteristics and also with reference to how these teams proceed in order to integrate internal functions toward the accomplishment of common goals.

\begin{tabular}{cllccc}
\hline Companies & \multicolumn{1}{c}{ Sector } & Annual Revenue & CFTs Surveyed & Team name & Number Interviewed \\
\hline Organization I & Agrochemicals & $\mathrm{R} \$ 300$ million & $\mathrm{I}$ & MPP (Monthly Production Planning) & 7 \\
Organization 2 & Beverages & $\mathrm{R} \$ 890$ million & $\mathrm{I}$ & IP (Integrated Planning) & 8 \\
Organization 3 & $\begin{array}{l}\text { Toiletries and } \\
\text { Beauty }\end{array}$ & $\mathrm{R} \$ 22,8$ billion & 2 & DP (Demand Planning) and PMO & 7 \\
& & & (Project Management Officer)
\end{tabular}

Table 2. Characteristics of the surveyed companies

\begin{tabular}{ll}
\hline Companies & \multicolumn{1}{c}{ Interviewees } \\
\hline Organization I & Marketing Manager, Commercial and Marketing Analyst, Logistics Manager, Logistics Supervisor, Planning and Control \\
& Manager, Human Resources Supervisor, Technical Sales Representative \\
\hline Organization 2 & Marketing Manager, Marketing Coordinator, Logistics Manager, Logistics Coordinator, Sales Manager, Strategic Plan- \\
& ning Manager, Human Resources Manager, Control Manager \\
\hline Organization 3 & Marketing Officer, Head of Regional Marketing, Logistics Coordinator, Export Logistics and Distribution Center \\
& Coordinator, Demander, Project Management Officer, Wholesale Sales Manager \\
\hline
\end{tabular}

Table 3. Organizations and respective interviewees

\begin{tabular}{ll}
\hline \multicolumn{1}{c}{ Procedures } & \multicolumn{1}{c}{ Description } \\
\hline $\begin{array}{l}\text { Transcript of in-depth interviews } \\
\text { recorded in audio }\end{array}$ & $\begin{array}{l}\text { Interviews were transcribed to facilitate textual analysis and use essential parts of speech in the } \\
\text { written analysis. }\end{array}$ \\
\hline Pre-analysis of transcripts & $\begin{array}{l}\text { Quick reading, early identification of possible categories based on the theory observed in the liter- } \\
\text { ature. }\end{array}$ \\
\hline In-depth analysis & $\begin{array}{l}\text { Systematic reading of the transcripts oriented by the separation of phrases in the text and relating } \\
\text { of these phrases with record units, defined by their semantic representation. Besides the analysis of } \\
\text { written text, the audio of all the interviews was analyzed to safely identify audible expressions that } \\
\text { could change the context or semantic meaning of the phrase. }\end{array}$ \\
\hline Description of record units (ele- & $\begin{array}{l}\text { After locating the record units, the particular meaning of each of these elements was arranged in } \\
\text { tables, considering the answers of each respondent and then characterized them in depth. }\end{array}$ \\
\hline ments and respective meaning) & The record units were grouped into three categories of cross-functional teams characteristics and \\
additional three categories representing the respective impacts of CFT over: a) cross-functional \\
integration, b) team results and, c) firm results.
\end{tabular}

Table 4. Stages of content analysis conducted in the research

ISSN: 07 I8-2724. (http://www.jotmi.org)

Journal of Technology Management \& Innovation (c) Universidad Alberto Hurtado, Facultad de Economía y Negocios. 
The interviews were recorded with the participants' permission, then transcribed and subjected to the content analysis technique. Content analysis is the study of verbatim transcripts of data in order to compare, observe differences and categorize factors in the text by means of information processing (Bauer and Gaskell, 2002). This process provides a systematic and objective identification of specific characteristics. Based on the literature recommendations (Bardin, 2008; Bauer and Gaskell, 2002), the steps used to perform the content analysis are outlined in Table 4.

After an in-depth analysis of each case, a cross-case analysis was performed. This procedure was performed to look for patterns or heterogeneity between the elements by comparing the coding obtained in each individual case. After identification and coding of the elements found in the analysis of content, themes were characterized semantically considering the context. The cross-case analysis was based on comparing and contrasting the types and meanings of the codes found in each organization surveyed (Barratt, Choi, and Li, 20I I;Yin, 2005). Such procedure provided a variety of elements concerning implementation strategies and impacts among the three cases, as presented in the next section.

\section{Results}

In the three companies surveyed, four different types of cross-functional teams were analyzed. The interviewees were asked to freely answer questions about teams' processes, structure, objectives as well as its impacts. Therefore, several teams' characteristics were identified through content analysis. These characteristics were grouped into six main categories of a framework:

- team procedures: characteristics of occurrence, mechanisms and periodicity;

- application context: characteristics of team's environment and specific goals;
- $\quad$ power distribution: concentration or balancing of power among members;

- impacts on cross-functional integration: how can CFT contribute to integrate internal functions?

- impacts on team results: which team characteristics contribute for the achievement of CFT particular goals?

- impacts on firm results: what benefits can be reached through the use of CFT at the company level?

The proposed framework includes these categories, and is illustrated by Figure I.

These categories and the relationship between them are explained in the forthcoming sections. A number of possible opportunities to arrange and characterize specific aspects of a highly performing cross-functional team are discussed.

\section{Team Procedures}

Based on the content analysis of the interviews, the procedures of the teams at each of the case study organizations were classified into three categories: occurrence, mechanisms and periodicity. Occurrence defines the team as permanent or temporary. Permanent teams are responsible for decision making over perennial firm processes and tasks.Alternatively, in a temporary team, the members are engaged with the group only until the conclusion of each project.

The mechanisms concern the integration factors used to set the internal functions tied in a way that they could work together and perform teams' activities. For all of the cases studied, the most important mechanism observed was the cross-functional meetings. The periodicity refers to the frequency in which the members effectively gather to make plans and take decisions related to the team responsibilities. Table 5 synthesizes the main characteristics of the procedures of the studied teams.

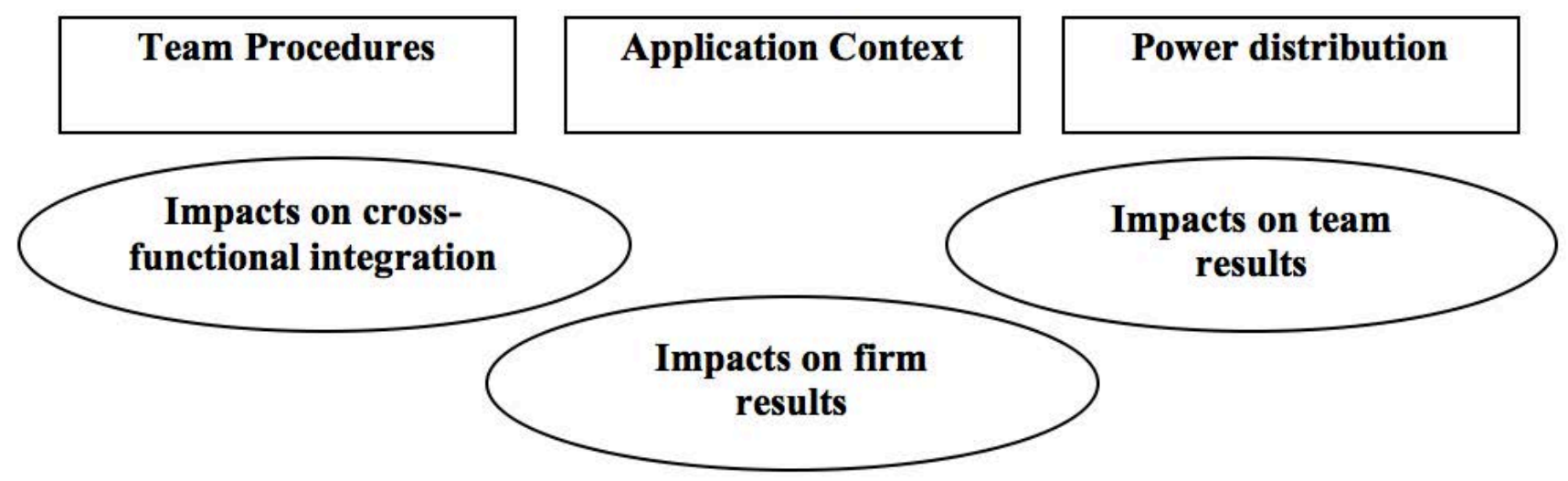

Figure I. Main categories of cross-functional teams characteristics and respective impacts

ISSN: 07 I8-2724. (http://www.jotmi.org)

Journal of Technology Management \& Innovation (c) Universidad Alberto Hurtado, Facultad de Economía y Negocios. 
The Monthly Production Planning (MPP) is a team aimed to define the monthly production plan with members from the areas of Marketing, Sales, Production and Logistics. Such a plan is defined from the demand forecast prepared by Marketing. The areas of Sales, Production and Logistics elaborate functional short term plans to meet the demand anticipated by Marketing. The MPP team carries out monthly regular meetings, but their members interact daily for adjustments of tasks and goals informally, by direct contact, instant messenger or phone. As one participant noted:

These meetings are mandatory ways of formal communication, but if you get through the corridor, it is also very easy to talk to people, to solve things, they easily answer questions. (MPP Team - Marketing Manager)

Integrated Planning (IP) is a team that works with regular monthly meetings, special meetings when necessary and also interacts informally for adjustments. It performs planning and decision making for long, medium and short terms, in the operational, marketing and administrative fields. It is composed of members of Marketing, Sales, Logistics, Production and Planning. They all have decision-making and negotiation powers. The IP has an extensive recognition within Organization 2, and this characteristic increases the desire of organizational members to participate and be part of the group. Therefore, the IP team generates a sort of informal motivational system. As mentioned by two of the interview participants:

To become an IP's member gave us some motivation, power and status (IP Team - Sales Manager). It generates some status, when a person is selected to became a member he feels motivated (IP Team - Strategic Planning Manager).
Demand Planning (DP) is a department that manages several permanent cross-functional teams, one for each product line. Teams are operationalized by the figure of the 'Demanders', whose function is to adjust the short-term forecast and coordinate the demand chain. The Demanders coordinate teams, which are also composed of members from the fields of Marketing, Sales and Production, which meet monthly. The DP team also has the goal to manage the Sales and Operations Planning (S\&OP) though joint planning of monthly Operations and Logistics needs from the demand forecast numbers. One participant on this team mentioned that:

Our main responsibility is to take care of the forecast and the product availability in the distribution centers in order to assure that the client always had the right product, at the right time and quantity. So, we go to the S\&OP meetings to make agreements about sales forecast, production capacity and logistics necessities (DP team - Demander).

The PMO is a department that manages several temporary cross-functional teams, one for each new product design. It performs two-weekly regular meetings and also interacts informally for adjustments. These teams manage the stages of development of new products and verify the feasibility of projects, interacting with Marketing, which develops ideas, as well as R\&D that investigates materials and processes.

The PMO is the central of projects, a kind of brain. It commands the whole process of product project, and has all information about it (PMO - Head of Regional Marketing).

The management system of new product projects in the PMO team is structured in a way that integrates different functions. When a new project is started, people from R\&D,

\begin{tabular}{llll}
\hline & \multicolumn{2}{c}{ Team } & \multicolumn{1}{c}{ Mechanisms } \\
\cline { 2 - 4 } & Occurrence & \multicolumn{1}{c}{ Periodicity } \\
\hline MPP & Permanent & Inter-functional Meetings & Monthly \\
One team & & Joint planning & Weekly \\
IP & Permanent & Inter-functional Meetings \\
\hline DP & & Joint planning & Monthly \\
Several teams, one for each line & Permanent & Inter-functional Meetings & \\
& & Joint planning & \\
\hline PMO & & Departmental structure to integrate functions & Fortnightly \\
Several teams, one for each project & & Inter-functional & \\
\hline
\end{tabular}

Table 5. Team procedures of the studied cases

ISSN: 07 I8-2724. (http://www.jotmi.org)

Journal of Technology Management \& Innovation (c) Universidad Alberto Hurtado, Facultad de Economía y Negocios. 
Marketing, Production and Logistics are selected to join the team, sharing their knowledge and taking decisions over the potential product. People from Logistics and Production eventually are added to the team that manages the project to assist where needed.

PMO is the main communication channel between supply chain and marketing. Demand Planning also do that, but in a commercial standpoint. PMO is concerned with those linkages in the new product development point of view. So, we integrate every area which are related to new product development (PMO Team - Project Management Officer).

\section{Application Context}

The application context denotes which processes the crossfunctional team is focused on. The team's goals might be related to the results of these processes, considering preferred aspects of performance. The studied teams operate in a context of integration between supply and demand, involving areas that deal with both the demand (Marketing, R\&D, Demand Planning) and supply sides (Production, Logistics). It was possible to identify that these teams deal with three main processes: I) Internal Operations Processes; 2) Demand and Supply Management; 3) NPD, that configures as a project management team. Table 6 presents the main application processes of the studied teams.
In the MPP team, the main responsibility is related to the operations processes management, i.e., to plan the necessary resources and activities to the monthly production, according to the demand forecast provided by Marketing.

As we work with agrochemicals, the Marketing campaigns are organized according to the occurrence of plant diseases. These diseases generally emerge in definite periods over the year. The PPM team works with joint planning, because Production and Logistics must to adapt themselves to assure that the products will be available in the field before disease risk (MPP Team - Marketing Manager).

The primary responsibility of both the IP and DP team is the alignment of demand and supply, concerning not only Production and Logistics issues, but all subjects related to the demand management planning in both the short and long terms. It includes the negotiation between internal areas in order to align Marketing and Sales strategies with Supply and Operations capacities. Some comments regarding responsibilities came from case participants.

If Production identifies a possible lack of products, they must communicate in the IP meeting and so, Supply Management will look for third parties to answer the demand (IP team Marketing Coordinator).

\begin{tabular}{ll}
\hline Team & Attributions/ Context \\
\hline MPP & Demand forecast \\
Monthly production planning & Purchasing, inventory and transportation planning \\
IP & Demand Planning \\
& Operations Planning \\
& Planning of changes required by senior management or the franchisor \\
DP & Demand forecast and planning \\
PMO & Nales and Operations Planning management \\
& New product project approvals \\
&
\end{tabular}

Table 6.Application Processes of the studied cases

ISSN: 07 I8-2724. (http://www.jotmi.org)

Journal of Technology Management \& Innovation (c) Universidad Alberto Hurtado, Facultad de Economía y Negocios. 
If, for example, Marketing forecast a too little amount of products, but we have the knowledge about demand and we know that probably a larger amount is going to be demanded. So, these numbers are sent to Production and Logistics, but everybody will realize that demand is rising and a possible lack of product is going to happen. So we make some adjusts (DP team - Demander).

Therefore, DP and IP teams are primarily concerned with joint planning and decision taking about supply and demand processes management, a common practice in the studied cases. The characterization of this type of cross-functional team was not found in the studied literature, but there are a few studies limited to the field of internal operations (Lichtenstein et al., 2004).

Finally, the PMO team manages the projects of NPD of the Toiletries and Beauty Products Company. Most part of literature in cross-functional teams is concerned with NPD and introduction (Henke et al., 1993; Feng et al. 2010) and project management (Pinto et al., 1993; Kotlarsky et al., 2012) application contexts.

\section{Power distribution}

If the power among members is not balanced, the decisions may be pointed to the interest of one single area, which may not favor inter-functional integration and common firm goals.As cited by Ghobadi and D'Ambra (20I2), the competition for political interests within CFT negatively affects both communication and boundary spanning activities. This type of effect is not desired in CFT application, because it spe- cifically aims at reducing hierarchical centralization through power division among functions (Henke et al., 1993).

Following this thought from literature, three types of power distribution were discovered in the studied teams: I) power balanced between members with full participation; 2) balanced between members with limited participation; 3) concentrated in some internal function. Table 7 explains the meaning of each of these configurations.

Only the IP team presented balanced power between members with full participation i.e., the decision making power is not concentrated in one or few team members, and also, all functions involved in the operations processes have a delegate within the team.

The IP leaders are yearly voted. They must not have any high level management function in the company, in order to keep the power balance over diverse hierarchical levels. When Marketing people start to be jealous to transfer a duty to another area, in order to get the credits by their own, so the team leader encourage them to divide, to delegate and to keep contact with other functions (IP team Marketing Coordinator).

The DP and PMO teams presented balanced power between members with limited participation. The PMO team members are Marketing, the Project Officer and NPD. Logistics and Production may be added in some projects, but they have only an assessing role, without decision power.The DP team is composed of Demanders, Marketing, Sales and Production. However, Logistics does not participate, which often causes some complaints from that function.

\begin{tabular}{|c|c|c|}
\hline Team & Power distribution & Meaning \\
\hline MPP & Concentrated in Marketing & $\begin{array}{l}\text { The power of decision is concentrated in one function or hierar- } \\
\text { chical level.The remaining members have low opportunity to inter- } \\
\text { act in the decision making }\end{array}$ \\
\hline IP & Balanced between members with full participation & $\begin{array}{l}\text { There's participation of members from all functions involved in } \\
\text { the processes managed by the team, each function with the same } \\
\text { weight for decision taking }\end{array}$ \\
\hline DP & $\begin{array}{l}\text { Balanced between members with limited participation. } \\
\text { Logistics do not participate }\end{array}$ & $\begin{array}{l}\text { The decision power is concentrated in the group members, but } \\
\text { not in all functions involved in the processes managed by the team }\end{array}$ \\
\hline
\end{tabular}

PMO Balanced between members with limited participation. The decision power is concentrated in the group members, but Logistics and Production have no power of decision not in all functions involved in the processes managed by the team

Table 7. Power Distribution in the studied teams

ISSN: 07 I8-2724. (http://www.jotmi.org)

Journal of Technology Management \& Innovation (c) Universidad Alberto Hurtado, Facultad de Economía y Negocios. 
We don't have an active participation (on the team), I guess we should have a more intense participation in the Marketing projects, but here we are a bit distant (PMO team Logistics Coordinator).

The MPP team works with all functions involved with the monthly production planning: Marketing, Sales, Logistics (supply and final products) and Production. The power of decision is concentrated in the Marketing function, which defines the demand forecast requirements in terms of production volume, product types and product delivery characteristics. In some occasions, the numbers provided by Marketing to the team are too shorter than sales effectively achieved.

Marketing heads the demand planning, with its numbers, so it can interfere in the process. Logistics people, in some periods of the year, almost get crazy because there is a huge concentration of sales at the end of month. So, there is a possible lack of trucks to deliver products (PPM team - Logistics Manager).

The remaining members have some opportunity to interact in the decision making, but Marketing has the final decision that has to be followed by Production and Logistics.

\section{Impacts}

After considering the characteristics of the CFT, the interviewees were asked to explain the impacts of using such teams. Through content analysis and coding, the mentioned impacts were categorized as impacts on crossfunctional integration, impacts on team results and impacts on firm results.

\section{Impacts on cross-functional integration}

Based on the content of Table 8, it is possible to draw some insights about the influence of CFT over internal integration. Interviewees perceived that the use of CFT helped to generate inter-functional integration as these teams required joint planning of tasks, improving the quality of decision making and goal alignment. As mentioned by Henke et al., (1993) CFT provide better quality of decisions in comparison with individual decisions.

Another impact is the influence of CFT over inter-functional informal integration. The use of CFT consist as a formal mechanism toward inter-functional integration, however, it can also generate informal integration factors due to the people's familiarity within the teams. Therefore, the more the people interact in the teams' activities, the more they develop mutual knowledge, confidence and team spirit. For example, concerning longevity of inter-personal relationship there have been a number of researchers that contributed (Ellinger, Keller, and Hansen, 2006; Kraiselburd and Watson, 2007; Maltz and Kohli, 2000).

\section{Impacts on team results}

These results are directly related with the effectiveness on the attributions of each team i.e., when CFT operates properly, hopefully they might reach their respective goals. Several authors have performed research about characteristics that promote CFT success (Proehl, 1997; Hauptman and Hirji, 1999; Katzenbach and Smith, 2003; Feng et al., 2010). The interviewees mentioned that the studied teams have the following objectives:

- MPP team: demand forecast, monthly production planning, purchasing, inventory and transportation planning; - IP team: demand planning, operations planning, planning of changes required by senior management or the franchisor;

- DP team: demand forecast and planning, sales and operations planning management;

- PMO team: new product project approvals, new product project management.

Considering the responsibilities of MPP, IP and DP teams, their effectiveness may be perceived through achievement of accurate demand planning numbers, or as close to actual as possible.

If members do not have the contact provided by teams, we may have fewer problems with forecast and it may negatively influence the supply of products (DP Team - Demander).

They are also places where members can negotiate to solve problems related to the bounded capacity of production, storage or transportation.

Thanks to IP, you get to understand other's problem, and make joint decisions (IP team - Marketing Manager).

It provides an efficient communication to achieve delivery appointments in the marketing promotional campaigns (MPP team - Technical Sales Representative).

Moreover, the PMO team has the responsibility to approve and manage the new product projects, in order to answer current market demands that have not been answered through the existing products.

When product ideas emerge, the PMO manages contacts between areas, manufacturing, finance, to verify if we can produce and distribute, and so we start to involve people from demand planning (PMO Team - Head of Regional Marketing). 


\begin{tabular}{|c|c|c|}
\hline Team & Impacts on Integration & Quotes \\
\hline MPP & $\begin{array}{l}\text { Cross functional teams are formal strategies that gener- } \\
\text { ate informal integration factors such as confidence and } \\
\text { team spirit because of constant interaction }\end{array}$ & $\begin{array}{l}\text { The formal meetings generate informal contact, and it increases } \\
\text { the knowledge about each other (MPP Team - Planning and Con- } \\
\text { trol Manager). }\end{array}$ \\
\hline IP & $\begin{array}{l}\text { CFT demands joint planning among functions for de- } \\
\text { mand planning } \\
\text { Functional teams are formal strategies that generate } \\
\text { informal integration factors as: mutual knowledge be- } \\
\text { tween areas, confidence and team spirit }\end{array}$ & $\begin{array}{l}\text { There are conflicts generated from market, we make adjusts to } \\
\text { answer it. The IP promote these adjustments, generating a com- } \\
\text { mon view of processes (IP team - Control Manager). }\end{array}$ \\
\hline DP & $\begin{array}{l}\text { Cross functional teams are formal strategies that gen- } \\
\text { erate informal integration factors such as confidence } \\
\text { and team spirit }\end{array}$ & $\begin{array}{l}\text { We go to the S\&OP meetings to make agreements about the } \\
\text { sales amount, and then, we inform the shop floor to produce } \\
\text { the right volume to send to the distribution centers (DP Team } \\
\text { - Demander). } \\
\text { We know ourselves very well, he (Demander) help me a lot. I call } \\
\text { him to ask for things all day long (DP Team - Marketing Officer) }\end{array}$ \\
\hline PMO & $\begin{array}{l}\text { CFT demands joint planning of: physical characteristics, } \\
\text { placement and communication for advertising, generat- } \\
\text { ing improvement on new products launch }\end{array}$ & $\begin{array}{l}\text { Often, people from demand planning, marketing, quality and man- } \\
\text { ufacturing gather and I think they have a strong interaction inside } \\
\text { these teams (PMO Team - Head of Regional Marketing). }\end{array}$ \\
\hline & $\begin{array}{l}\text { Cross functional teams are formal strategies that gen- } \\
\text { erate informal integration factors such as confidence } \\
\text { and team spirit }\end{array}$ & $\begin{array}{l}\text { It is like brothers, you may fight, fight, but when another person } \\
\text { starts to hurt him, you help your brother against the other (PMO } \\
\text { Team - Project Management Officer). }\end{array}$ \\
\hline
\end{tabular}

Table 8. Impacts of CFT on cross-functional integration

ISSN: 07I 8-2724. (http://www.jotmi.org)

Journal of Technology Management \& Innovation (c) Universidad Alberto Hurtado, Facultad de Economía y Negocios. 


\section{Impacts on firm results}

CFT reduce hierarchical centralization (Henke et al., 1993), conflicts and language barriers (Griffin and Hauser, 1996), speed-up processes, as well as help to maintain focus on the organization's broad goals (Maltz and Kohli, 2000). As these earlier literature findings, the interviewees cited that CFT may generate the impacts listed in Table 9.

According to the interviewees, the CFT chase their own goals that are aligned with company global indicators. Such an opinion means that CFT contribute to improved NPD process, deliveries, as well as reduce inventories, damages and lack of products in the market. These functional impacts are related to the reaching of global impacts like: customer satisfaction, improvement of the organization's image in the market, market share gain, and reduced logistics cost.

Another impact perceived by interviewees is that the interpersonal integration provided by CFT may reduce stress and misunderstanding between company employees. This impact primarily arises from the familiarity among team members, increasing people mutual knowledge, team spirit and confidence level.

A primary observation was that companies made different choices in terms of the goals and tasks of the cross-functional teams, the timing impact of their decisions (short or long term), connection with processes, strategies and structure definitions, formality or informality prevalence and power structure. Also, diverse benefits are perceived in the different organizations.

\section{Discussion and Implications}

This research provides an exploratory framework regarding the organization of cross-functional teams. Based on the surveyed cases, Figure 2 demonstrates the team characteristics: procedures, application context and goals, power distribution, impacts on cross-functional integration, impacts on the performance of team and organization.

\begin{tabular}{|c|c|c|}
\hline Team & Impacts on Team Results & Quotes \\
\hline MPP & $\begin{array}{l}\text { Avoidance of delays, damages and lack of products; } \\
\text { Customer satisfaction; } \\
\text { Reduced logistics cost; } \\
\text { Decrease in inventories; } \\
\text { Avoidance of employee stress }\end{array}$ & $\begin{array}{l}\text { That production planning meeting is the key to avoid lack } \\
\text { of products in the market and to avoid that company be } \\
\text { hampered due to excessive inventories, because it has a } \\
\text { unnecessary cost (MPP Team - Marketing Manager) }\end{array}$ \\
\hline IP & $\begin{array}{l}\text { Avoidance of delays, damages and lack of products; } \\
\text { Customer satisfaction; } \\
\text { Improvement of the organization's image in the market; } \\
\text { Avoidance of employee stress }\end{array}$ & $\begin{array}{l}\text { In cases of advertising campaigns of new products, the } \\
\text { integration provided by IP helps to deliver products at the } \\
\text { right time, improving the customer satisfaction and the } \\
\text { strengthening of the brand (IP Team - Marketing Coordi- } \\
\text { nator) }\end{array}$ \\
\hline DP & $\begin{array}{l}\text { Avoidance of delays, damages and lack of products; } \\
\text { Customer satisfaction; } \\
\text { Reduced logistics cost; } \\
\text { Improvement of the organization's image in the market; } \\
\text { Avoidance of employee stress }\end{array}$ & $\begin{array}{l}\text { Thanks to the integration of internal functions, we can } \\
\text { deliver the right thing at the right place and just in the } \\
\text { right time.And so, we can satisfy the client (Opinion of } \\
\text { Logistics Coordinator about DP Team) }\end{array}$ \\
\hline PMO & $\begin{array}{l}\text { Market Share gain } \\
\text { Avoidance of employee stress }\end{array}$ & $\begin{array}{l}\text { Since I have not a product available in the market, I'm go- } \\
\text { ing to lose market share, so marketing and the other func- } \\
\text { tions must be integrated as a team (PMO Team - Head of } \\
\text { Regional Marketing) }\end{array}$ \\
\hline
\end{tabular}

Table 9. Impacts of CFT on firm performance

ISSN: 07 I8-2724. (http://www.jotmi.org) 
The teams' procedures may be categorized in terms of occurrence, mechanisms and periodicity. The application context is concerned with the processes that the crossfunctional team deals with, and the achievement of goals related to these processes expected results. The decision power among teams may be unbalanced, and the decisions may be pointed to the interest of one single area. However, a more balanced sharing of power among members may favor inter-functional integration and the achievement of common firm goals. Therefore, balanced power sharing, as well as procedures aligned with the context needs may reflect in the achievement of positive impacts.

\section{Managerial Implications}

According to the studied cases, there is a perception that CFT generate several benefits in firm results. In order to reach them, managers should be familiar with teams' structural dimensions (i.e., procedures, application context and goals, power distribution) as well as their operational functioning. The familiarity with these elements may provide some insights for managers to improve the manufacturing process.
Managers should first support teams in establishing an environment in which prevails the balance of power among team members. This type of action creates a clear sense of group performance and contributes to the definition of non-conflicting goals within teams. Moreover, such an environment can help team members feel comfortable enough to express their individual opinion and make contributions to the team. As earlier mentioned by Mentzer, Stank, and Esper (2008), when responsibility is given solely to a functional actor, then there may be sub-optimization of results.

Another managerial insight concerns the formality of meetings. This formalization process was identified as one of the most important mechanisms in the teams' procedures. Managers should closely observe the procedures of these meetings to understand and identify how the power flows through the decision making processes. Moreover, managers should be aware that team meetings cannot be the only mechanism that provides contact between team members. It seems necessary to stimulate people to gather in other activities, in order to generate mutual understanding over the time. Such attempts may increase trust and group spirit within teams, improving the solving of inter-functional conflicts related to their processes and, consequently, generating benefits for their application contexts.

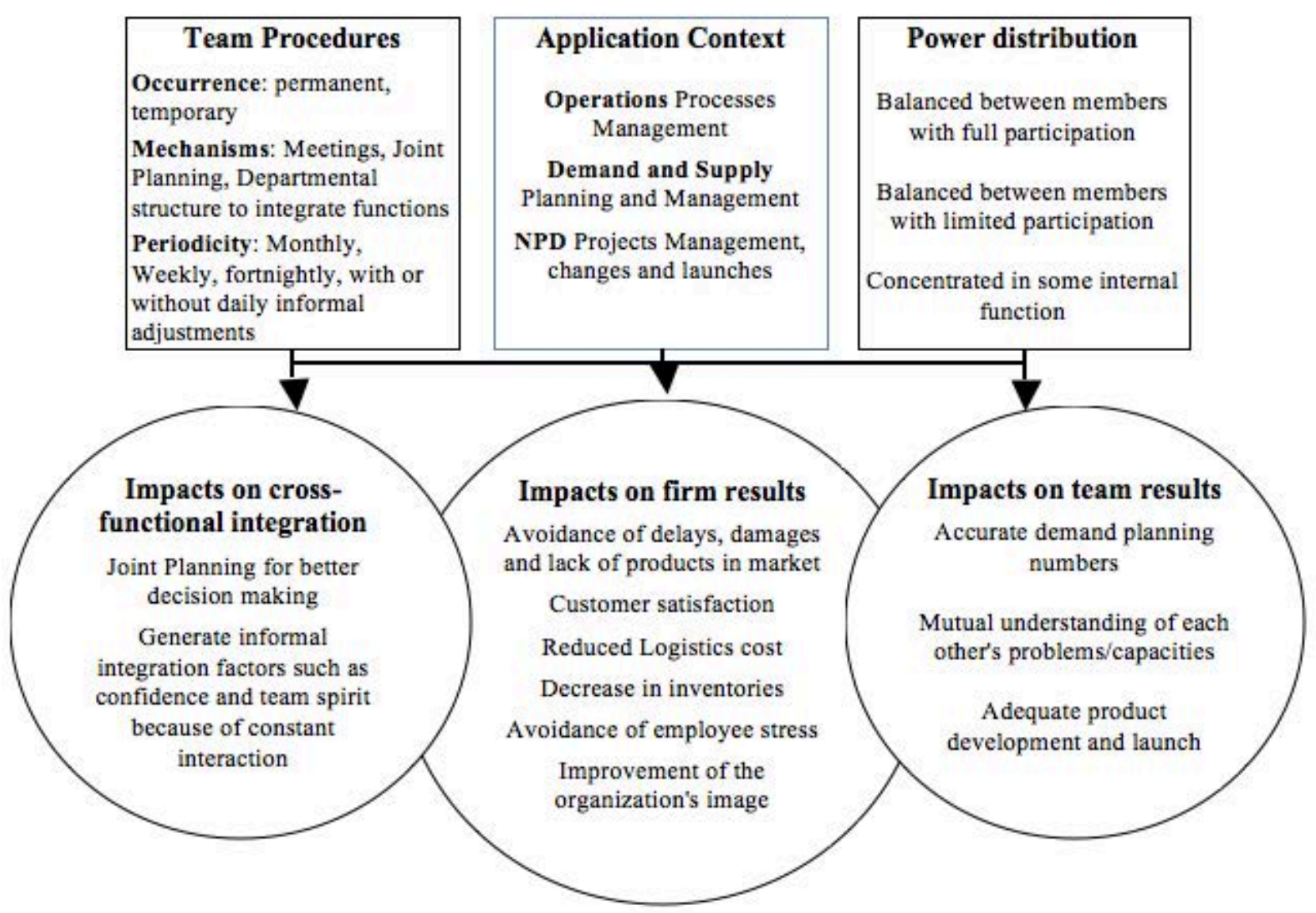

Figure 2. Characteristics of Cross-functional teams and respective impacts

ISSN: 07I 8-2724. (http://www.jotmi.org)

Journal of Technology Management \& Innovation (c) Universidad Alberto Hurtado, Facultad de Economía y Negocios. 
Many organizations in Brazil and elsewhere do not use CFT efficiently because of a lack of knowledge about that tool and its respective benefits. The proposed framework can help managers effectively assess team structure and behavior, in order to provide understanding about which operational factors are related to each performance elements. Specifically about the context of demand and supply management, managers should consider demand planning as a permanent task performed by CFT that includes, not only Sales and Marketing, but also Logistics and Production members. Such configuration may predict unfavorable situations that require a quick response from different functions, foster communication and expand mutual understanding among functions.

\section{Theoretical Implications}

This research presents specific characteristics about teams that are responsible for process management in manufacturing companies, a theme that is very poorly mentioned in the extant literature about CFT. Most of the literature regarding cross-functional teams is concerned with NPD (Henke et al., 1993; Feng et al. 2010) and project management (Pinto et al., 1993; Kotlarsky et al. 2012) application contexts. In addition, there is no research that mentions the characteristics of groups designed to address both sides of the demand and supply management equation.

In addition to the current literature, and also, considering the context of demand and supply management, the proposed framework offers a perspective to study CFT characteristics, with a foundation established from categories observed in the field research. From this analytical perspective, power sharing can be balanced among members by effectively establishing the team and enabling team management. By doing this, positive impacts on integration, and, consequently, results of team and of firm may be achieved.

\section{Future Research}

This CFT framework details practices, structures and objectives and allows for research on the three types of impacts related to CFT application. Such a perspective can provide more complete analyses than previous models, particularly as it concerns the causal relationships between practices and team performance. The proposed framework may be complemented and expanded in terms of its internal elements and their respective behavioral dynamics in future research that relates to the following proposals.

I. Research design: the qualitative collection and analysis methods used for this research serves as a limiting factor in that it can neither obtain amplitude with respect to sampling nor generalize results. As a suggestion for future work quantitative research might be can be carried out in order to study the correlation between the characteristics of team (Team Procedures, Application Context and Power distribution) and its respective impacts (on integration, on teams, on firm as a whole). Managers could then use this information to understand how cross-functional teams can positively impact performance.

2. Framework elements: future research may complement and expand upon the elements of the current framework, and classify them within the five basic categories. The current framework elements were found through Grounded Theory principles, directly from field research. Therefore, either systematic literature review and/or qualitative field research in other industries may contribute increasing number of teams' characteristics, as well as proposing aspects that influence results. This type of knowledge can provide a robust and wide support for development of future research on teams characteristics, performance and possible relationships among them.

3. Application context: this is an important element within the framework that can present different characteristics depending on the type of company. These characteristics vary due to the specific role that the CFT plays within the firm, but they also may vary when applied in different industries and organizational cultures. Future research can help to deepen the understanding of this element in different contexts and provide extensions of the framework.

4. CFT members' skills: as the current investigation was primarily concerned with teams' processes, some issues related to human resources were not addressed. Future research may investigate about the necessities of the teams in terms of members' skills, specifically in processes related to demand and supply management, in order to address questions like: a) which functions should be included? b) what are the necessary skills and knowledge? c) which individual skills are adequate for each configuration of CFT? Richer qualitative data can be collected through observation of team meetings, in depth interviews and analysis of meeting documents.

5. Team operationalization and power division: Logistics and Production are not always included in decision-making processes within CFT.These functions often have limited power to influence teams, generating unbalanced power and, consequently, affecting negatively performance. Another paramount element that influences CFT performance is the mutual existence of formal and informal mechanisms used to arrange team members in a way that facilitates performance. Future research may investigate the balance of power within the teams and the influence of formal mechanisms (meetings, documents and training) and informal mechanisms (mutual understanding and trust). This type of investigation may 
clarify how team procedures can influence power aspects of the team, and how the interaction between these two CFT characteristics affects the performance of companies.

As discussed in the earliest part of this paper, Brazilian industries must adopt managerial tools based in cultural traits driven by processes and products innovation due to its current necessity of improvement. This paper results provided several managerial perceptions about how cross-functional teams can operate in order to improve integration processes, teams' processes and company's performance items. Such perspective implies in "getting your own house in order" as a first step before develop effective and innovative initiatives along the supply chain.

\section{References}

ANTHONY, E. L., Green, S. G., and McComb, S. a. (20I3). Crossing functions above the cross-functional project team: The value of lateral coordination among functional department heads. Journal of Engineering and Technology Management. DOI:10.1016/j.jengtecman.2012.12.00I.

BARDIN, L. (2008). Análise de conteúdo. Lisboa: Edições 70.

BARRATT, M., Choi, T.Y., and Li, M. (20I I). Qualitative case studies in operations management: Trends, research outcomes, and future research implications. Journal of Operations Management, 29(4), 329-342. DOI:10.1016/j. jom.2010.06.002.

BAUER, M., and Gaskell, G. (2002). Pesquisa qualitativa com texto, imagem e som: um manual prático. Petrópolis:Vozes.

DASPIT, J., Tillman, C. J., Boud, N. G., and Mckee, V. (20I3). Cross-functional team effectiveness: An examination of internal team environment, shared leadership, and cohesion influences. Team Performance Management, 19(I), 34-56.

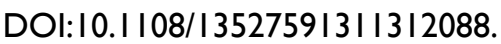

DAUGHERTY, P. J., Chen, H., Mattioda, D. D., and Grawe, S. J. (2009). Marketing/logistics relationships: influence on capabilities and performance. Journal of Business Logistics, 30(I), I-19. DOI: I0.1002/j.2I58-I592.2009.tb00096.x.

ELLINGER, A. E., Keller, S. B., and Hansen, J. D. (2006). Bridging the divide between logistics and marketing: facilitating collaborative behavior. Journal of Business Logistics, 27(2), I-28. DOI: I0. I002/j.2 I58-I592.2006.tb002 I5.x.

FENG, B., Jiang, Z.-Z., Fan, Z.-P., and Fu, N. (2010). A method for member selection of cross-functional teams using the individual and collaborative performances. European Journal Of Operational Research, 203(3), 652-66I. DOI:10.1016/j. ejor.2009.08.017.
FLINT, D. J., Larsson, E., and Gammelgaard, B. (2008). Exploring processes for customer value insights, supply chain learning and innovation: an international study. Journal of Business Logistics, 29(I), 257-282. DOI: 10.1002/j.21581592.2008.tb00078.x.

GHOBADI, S., and D'Ambra, J. (2012). Knowledge sharing in cross-functional teams: a coopetitive model. Journal of Knowledge Management, 16(2), 285-301. DOI: 10.1 108/1367327/21/218889.

GLASER, B. G., and Strauss, A. L. (1967). The discovery of Grounded Theory: strategies for qualitative research (Ist ed.). New York:Aldine Pub. Co.

GRIFFIN, A., and Hauser, J. R. (1996). Integrating R\&D and Marketing: A Review and Analisis of the Literature. Journal of Product Innovation Management, 13, |9|-215. DOI: 10.1016/0737-6782(96)00025-2.

HAUPTMAN, O., and Hirji, K. K. (1999). Managing integration and coordination in cross-functional teams: an international study of Concurrent Engineering product development. R \& D Management, 29(2), 179-192. DOI:10.1III//4679310.00128 .

HENKE, J.W., Krachenberg, a R., and Lyons, T. F. (1993). Perspective - Cross-Functional Teams - Good Concept, Poor Implementation. Journal of Product Innovation Management, I0(3), 2I6-229. DOI: I0. I016/0737-6782(93)90027-N.

HILLETOFTH, P., Ericsson, D., and Christopher, M. (2009). Demand chain management: a Swedish industrial case study. Industrial Management and Data Systems, 109(9), II79| |96. DOI:10.1 108/02635570911002261.

HOLLAND, S., Gaston, K., and Gomes, J. (2000). Critical success factors for cross-functional teamwork in new product development. International Journal of Management Reviews, 2(3), 23 I-259. DOI: I 0.1 I I I/ I468-2370.00040.

JUGEND, D., and Silva, S. L. (20I2). Management and Innovation Integration in New Product Development: Case Study in a Large Brazilian High-Technology Company. Journal of Technology Management Innovation, 7(I), 52-63. DOI: http:// dx.doi.org/I0.4067/S07| 8-272420I 2000100004.

KAHN, K. B. (1996). Interdepartmental integration: a definition with implications for product development performance. Journal of Product Innovation Management, 13, I37I5I.DOI: I0.1016/0737-6782(95)00II0-7.

KATZENBACH, J. R., and Smith, D. K. (1993). The discipline of teams. Harvard Business Review, 7 I (2), I I I-I 20. 
KATZENBACH,J. R., and Smith, D. K. (2003).The Wisdom of Teams (Ist ed.). New York: First Harper Business.

KOTLARSKY, J., van den Hooff, B., and Houtman, L. (20I2). Are We on the Same Page? Knowledge Boundaries and Transactive Memory System Development in CrossFunctional Teams. Communication Research, 26. In press. DOI: I0.II77/00936502I2469402.

KRAISELBURD, S., and Watson, N. (2007). Alignment in Cross-Functional and Cross-Firm Supply Chain Planning Alignment in Cross-Functional and Cross-Firm Supply Chain Planning. Working Paper, (May), I-39.

LAMBERT, D. M., and Cook, R. L. (1990). Integrating Marketing and Logistics for Increased Profit. Business, 40(3), 22-29.

LEAHY,J. (20I4). Central bank data suggests Brazil slid into recession last year. Financial Times, available at <http://www. ft.com/intl/cms/s/0/926777cc-95a I- I l e3-837 I-00 I 44feab7de.html>, accessed at March, 2014.

LICHTENSTEIN, R., Alexander, J. a, McCarthy, J. F., and Wells, R. (2004). Status differences in cross-functional teams: effects on individual member participation, job satisfaction, and intent to quit. Journal of Health and Social Behavior, 45(3), 322-335. DOI: 10.1 I77/0022 I4650404500306.

LYNCH, J., and Whicker, L. (2008). Do logistics and marketing understand each other? An empirical investigation of the interface activities between logistics and marketing. International Journal of Logistics, II(3), I67-178. DOI: $10.1080 / 13675560701602708$.

MAJCHRZAK, a, More, P. H. B., and Faraj, S. (20I2). Transcending Knowledge Differences in Cross-Functional Teams. Organization Science, 23(4), I-20. DOI:10.1287/ orsc. III 0.0677.

MALTZ, E., and Kohli, A. K. (2000). Reducing Marketing 's Conflict With Other Functions: The Differential Effects of Integrating Mechanisms. Journal of Academy of Marketing Science, 28(4), 479-492. I0.I I77/0092070300284002.

MCDONOUGH III, E. F. (2000). Investigation of factors contributing to the success of cross-functional teams. Journal of Product Innovation Management, 17, 22I-235. DOI: 10.1016/S0737-6782(00)0004I-2.

MENTZER, J., Stank, T., and Esper,T. (2008). Supply chain management and its relationship to logistics, marketing, production, and operations management. Journal of Business Logistics, 29(I), 3I-46. DOI: 10.1002/j.2I58-I592.2008.tb00067.x.
PAGELL, M. (2004). Understanding the factors that enable and inhibit the integration of operations, purchasing and logistics. Journal of Operations Management, 22, 459-487. DOI:I0.1016/j.jom.2004.05.008.

PINTO, M. B., Pinto, J. K., and Prescott, J. E. (I993). Antecedents and Consequences of Project Team Cross-Functional Cooperation. Management Science, 39(10), I28I-1297. DOI:I0.1287/mnsc.39.10.128I.

PROEHL, R. A. (1997). Enhancing the effectiveness of crossfunctional teams. Team Performance Management, 3(3), |352-7592. DOI: |0.| |08/0|4377396|0| 27450.

RATCHEVA,V.(2009). Integrating diverse knowledge through coundary spanning processes - The case of multidisciplinary project teams. International Journal of Project Management, 27, 206-2 I5. DOI: I0.1016/j.jijproman.2008.02.008.

RHO, B., Hahmb, Y.-S., and Yu, Y.-M. (1994). Improving interface congruence between manufacturing and marketing in industrial-product manufacturers. International Journal of Production Economics, 37, 27-40. DOI: 10.1016/09255273(94)90005-I.

TOPOLŠEK, D., and Čurin, A. (20I2). The Role of Employee Relations in the Level of Internal Integration between Logistics and Marketing Functions: the Case of Slovenian Retail Companies, 45(I), 3-I3. DOI: 10.2478/v I005I-0I2-000 I-9.

TURKULAINEN, V., and Ketokivi, M. (20I2). the real benefits? Cross-functional integration and performance: what are the real benefits? International Journal of Operations and Production Management, 32(4), 447-467. DOI: I0.I I08/0 I 44357| I I I 223095.

WEBBER, S. S. (2002). Leadership and trust facilitating crossfunctional team success. Journal of Management Development, 2I (3), 20I-2 I4. DOI: I0.I I08/0262 I I I02 I 0420273.

YIN, R. (2005). Estudo de caso: planejamento e métodos. Porto Alegre: Bookman. 